\title{
整
}

\section{Psalm 40 as a Torah psalm ${ }^{1}$}

P. Styger

Centre for BMI

Potchefstroom Campus

North West-University

POTCHEFSTROOM

E-mail: bwips@puk.ac.za
Y. Steenkamp

Department of Old Testament Studies

Faculty of Theology

University of Pretoria

PRETORIA

E-mail:antieke.tale@up.ac.za

D.J. Human

Department of Old Testament Studies

Faculty of Theology

University of Pretoria

PRETORIA

E-mail: djhuman@ccnet.up.ac.za²

\begin{abstract}
Psalm 40 as a Torah psalm

This article investigates whether the Gattung of Torah psalm can be added to the current accepted Gattungen of Psalm 40. The characteristics and criteria for Torah-related and wisdomrelated concepts and their close interrelationship are discussed. The so-called characteristics of the Wisdom triangle and the Torah triangle are also explained. Psalm 119 as example of a Torah psalm is briefly discussed, indicating the interaction between wisdom-related and Torah-related concepts and identifying the criteria for a Torah psalm. The different words related to the Torah are identified in Psalm 119 and applied to identify other psalms possibly fitting the criteria for a Torah psalm. These psalms are then briefly evaluated-Psalm 40 as possible Torah-psalm in particular. It is concluded that the Gattung of Torah psalm can possibly be added to the current list of Gattungen associated with Psalm 40. The reference to the Torah in Psalm 40 possibly fits Torah-related concepts to a
\end{abstract}

1 Revised version of a paper read at the Pro-Psalm Conference, University of Pretoria, 19 August 2004.

2 The authors want to thank Professors Phil Botha and Piet Venter and Dr. Eduan Naudé for their helpful suggestions and comments on an earlier draft of the paper. At Lamprecht provided assistance with the Concordance research. 
greater extent than wisdom-related concepts. In final instance the conclusion arrived at is that the connotation associated with or the relationship between Torah-related and wisdom-related concepts in post-exilic Israel and its role in the final redaction of the Psalter merits further investigation.

\section{Opsomming}

\section{Psalm 40 as 'n Tora-psalm}

Hierdie artikel ondersoek die moontlikheid dat die Gattung van Tora-psalm bygevoeg kan word by die huidige erkende lys van Gattungen van Psalm 40. Die eienskappe van en kriteria vir Tora- en wysheidsverwante konsepte, asook hulle noue interaksie word bespreek. Ook die eienskappe van sogenaamde Tora- en wysheidsdriehoeke word verduidelik. Psalm 119 word kortliks bespreek as Tora-psalm, terwyl die interaksie tussen Tora-verwante en wysheidsverwante konsepte verduidelik word en die kriteria vir 'n Tora-psalm afgelei word. Die verskillende Tora-verwante woorde in Psalm 119 word geïdentifiseer en toegepas om ander psalms te identifiseer wat moontlik aan die kriteria van 'n Tora-psalm voldoen. Hierdie psalms word dan kortliks beoordeel - in besonder Psalm 40. Die gevolgtrekking word gemaak dat die Gattung van Tora-psalm moontlik by die huidige lys van Gattungen van dié Psalm gevoeg kan word. Die verwysing na die Tora in Psalm 40 pas waarskynlik meer in die Tora-konsep as in die Wysheidskonsep. Daar word aanbeveel dat die konnotasies en verhouding tussen Tora- en wysheidsverwante konsepte in die Israel van ná die ballingskap en die rol daarvan in die finale redaksionele samestelling van die Psalmbundel verder ondersoek moet word.

\section{Introduction}

The classification of psalms into different Gattungen (types), e.g. the Gattung of individual lament or of royal psalm, is well known (see e.g. Gillingham, 1994; Bratcher, 2002a \& b). Burger (1987:23) states that knowledge of the Gattung of a psalm is necessary to understand the psalm better. Some researchers, e.g. Whybray (1996) and Anon. (2004a), also include "Torah psalms" as a specific type of psalm. Although the word Torah appears in nine psalms, only Psalm 1 and Psalm 119 are regarded as "pure" Torah-psalms (Whybray, 1996:45-49), while other authors, like Mays (1987:3) add Psalm 19 as a third Torah-psalm.

Psalm 40 has drawn the attention of psalm researchers for several reasons - inter alia: 
- The debate whether this psalm condemns the offering of sacrifices.

- The question whether Psalm 40 comprises a single poem or whether two poems (Psalm 40 and Psalm 70) are possibly linked together.

- The quotation from the Psalm in Hebrews 10 (this allusion caused a debate relating to the meaning of the phrase in Psalm 40:7 regarding the opening or piercing of an ear).

Different opinions regarding the Gattung of the Psalm currently prevail.

In especially the Reformed Churches in South Africa (Gereformeerde Kerke in South Africa; GKSA) Psalm 40:4, as well as verses from Psalm 119 and Psalm 25:2, has for many years frequently been included in the liturgy and as a congregation's reply to the reading of the law (confessional/penitential psalm). In the minds of many people Psalm 40 is perceived, like Psalm 119, a Torah psalm. The question can be asked whether Psalm 40 can also be regarded as a Torah psalm ${ }^{3}$ - in addition to this psalm's other recognised and established Gattungen. Furthermore, the question whether Psalm 1, 19 and 119 are really the only Torah psalms also comes to the fore.

To answer these questions the research results obtained from investigating the existing Gattungen of Psalm 40 will be scrutinised and the results of this research will be given in summarised form. The concepts Torah and wisdom and their interrelationship will necessarily be part of the discussion. Furthermore, the possible characteristics of /criteria for a Torah psalm will be deducted from results obtained after the investigation of specific characteristics of Psalm 119. Other Torah psalms and possible Torah psalms will briefly be discussed according to the above criteria. The possible status of Psalm 40 as Torah psalm will then be evaluated and finally some concluding remarks will be made.

It is, however, important to remember Naudé's (1999: 172) important warning that every psalm is a unique independent text that will not necessarily fit into one of the Gattungen.

3 The aim of the article is not to criticise the use of the Totius versification of Psalm $40: 4$ as confessional/penitential psalm used in the liturgy. 


\section{Gattung(en) of Psalm $\mathbf{4 0}$}

The research into the Gattungen of Psalm 40 resulted in quite diverse views and conclusions. Firstly, the results of Naudé's (1999) comprehensive literature search will be summarised and then the views of other commentators will briefly be discussed.

Naudé (1999:155) concludes that the research into the Gattungen of Psalm 40 can be divided in two parts: firstly research/researchers' views concentrating on the possible division of the psalm into two distinct parts and secondly, research/researchers' views not concerned with this issue and conducting their investigation along different lines. The main conclusions of Naudé's study (1999:154172) can be summarised as indicated in Table 1 and 2:

Table 1: Gattungen research focusing on the two parts of Psalm 40

\begin{tabular}{|l|l|}
\hline Author & Gattungen \\
\hline Gunkel & $\begin{array}{l}\text { Individual thanksgiving } \\
\text { Individual lament }\end{array}$ \\
\hline Mowinckel & $\begin{array}{l}\text { Individual lament } \\
\text { Individual (private) thanksgiving } \\
\text { Song of praise } \\
\text { Song of blessing } \\
\text { Song of wrath }\end{array}$ \\
\hline Oesterley & $\begin{array}{l}\text { Individual thanksgiving (gratitude for recovery) } \\
\text { Individual lament (prayer to be delivered from } \\
\text { enemies) }\end{array}$ \\
\hline Ridderbos & $\begin{array}{l}\text { Thanksgiving (for deliverance) } \\
\text { Lament (prayer in distress) }\end{array}$ \\
\hline Westermann & $\begin{array}{l}\text { Individual thanksgiving (berichtende \& beschreiben- } \\
\text { de Lobpsalm) } \\
\text { Lament }\end{array}$ \\
\hline Weiser & $\begin{array}{l}\text { Song of praise } \\
\text { Lament (prayer) }\end{array}$ \\
\hline Braulik & $\begin{array}{l}\text { Song of confession } \\
\text { Individual prayer of lament }\end{array}$ \\
\hline Kraus & \begin{tabular}{l} 
Individual thanksgiving \\
\hline
\end{tabular}
\end{tabular}


Table 2: Other Gattungen research of Psalm 40

\begin{tabular}{|l|l|}
\hline Author & Gattungen \\
\hline Crüsemann & $\begin{array}{l}\text { Song of thanksgiving } \\
\text { Prayer of lament }\end{array}$ \\
\hline Eaton & Royal psalm \\
\hline Craigie & Royal liturgy of lament/supplication \\
\hline Gerstenberger & Complex prayer forming a liturgical unit \\
\hline Hossfeld \& & $\begin{array}{l}\text { Thanksgiving for deliverance } \\
\text { Conger } \\
\text { Lament and prayer }\end{array}$ \\
\hline Naudé & $\begin{array}{l}\text { Song of praise for deliverance } \\
\text { Confession } \\
\text { Supplication/prayer }\end{array}$ \\
\hline
\end{tabular}

The elements of songs/prayers of praise and lament form the main parts of most of the researchers' views. The instructions of the Torah or the supposed behaviour of those living according to it did not feature as one of the key elements identified.

The translators of the two Afrikaans translations of the Bible also "force" a Gattung onto the reader by adding a heading to the Psalm. In the 1933 translation it reads "Blessed is he who trusts in the Lord" (Welgeluksalig is hy wat op die Here vertrou) - a formulation which contains an element of praise and confession. In the 1983 translation the heading reads "Lord save/deliver me please/now" (Here, red my tog!) which relates to the Gattung of individual lament/ supplication/prayer. The heading of the Psalm in the King James Bible is "Praise for deliverance", which highlights the element of praise.

On the basis or the above brief discussion it can be concluded that although differences exist about the nature of the Gattung(en) of Psalm 40 the majority of the mentioned researchers acknowledge a combination of lament and a song of praise.

\section{Torah-related and wisdom-related concepts}

Mays (1987:3) indicates that the issue of Torah psalms and Wisdom psalms in the Psalter is not primarily related to their interpretation as isolated texts; the issue rather concerns the presence of Torahrelated and wisdom-related words and concepts in the Psalter and the implications for the way the Psalter is viewed and read. The 
relationship between piety associated with wisdom and that of piety associated with obedience to the Torah in the late post-exilic period is widely recognised. Whybray (1996:36) used, among others, the works of Ben Sira to indicate the close relationship of the two concepts and states that the "two streams" that proceeds from the mouth of $\mathrm{YHWH}$, namely the written Torah and the obedience to the teaching of wisdom eventually became one. Wilson (2003) concurs and states that the concept of wisdom in its origins appeared to have been founded on natural theology, that developed from the observation and experience of the world. Wilson (2003) proposes that at a later stage (the Exilic period) Israel's sages (wise men recognised for their wisdom in ancient times) equated the demands embedded in wisdom literature with the covenantal commandments of YHWH. According to Wilson (2003) this development can clearly be seen in the Apocrypha, in which the identification of elements of wisdom and the Torah as the revealed law and commandments of $\mathrm{YHWH}$ is complete. The concepts of wisdom-related and Torahrelated concepts and the perception of piety had a definite influence on the final redaction of the Psalter. 4

In order to study the possible classification of Torah psalms it is necessary to understand the close relationship between wisdomrelated and Torah-related concepts. A brief discussion of the concept of wisdom and the deduction of characteristics of the socalled Wisdom triangle will thus precede the discussion of Torah psalms.

\subsection{The concept of wisdom}

Although a few researchers, especially Crenshaw (2000:9-17; 2001:87-95 and 2003:155-158), challenge the idea of Wisdom psalms, the concept is widely accepted in subject-related literature (Wilson, 2003). The brief discussion of the characteristics of Wisdom psalms is based on sources that summarise the research on Wisdom psalms (including the pioneering work of Gunkel) - see Burger (1985; 1987), Kuntz (1974), Whybray (1995) and Anon. (2004c) in this regard. The different characteristics of the Wisdom psalms will briefly be discussed. It should, however, be noted that all characteristics are not necessarily found simultaneously in any one psalm. The presence of identifying wisdom-related characteristics in a psalm does not automatically classify a psalm as a Wisdom psalm.

4 For a detailed discussion on this topic, see Smith $(1991$; 1992) and McFall (2002), but also the discussions in Joffe (2001), Smith (1984), Wilson (1984; 1986; 1992; 1993; 2003) and others. 
Researchers point out that, among others, the frequency of characteristics occurring in Wisdom literature should be paid attention to. The essence of Wisdom literature will be discussed according to two sets of characteristics, namely rhetorical elements (Watts, 1999) and thematic elements.

\subsubsection{Rhetorical elements}

\section{- "Better"-sayings}

"Better"-saying comprises a comparison between two issues of which one is preferred to the other. This kind of saying is not found in Job, but is used 22 times in Proverbs and 18 times in Ecclesiastes, indicating that this way of expression clearly represents a key characteristic of formulating wisdom. This kind of saying occurs six times in the Psalter (Ps. 37:16; 63:4; 84:11; 118:9 and 119:72).

\section{- Numerical sayings}

In numerical sayings a number is mentioned (e.g. five) and directly after that the consecutive number (e.g. six) is mentioned, followed by a list of items equal to the last number. Numerical sayings also have a quizzica character intended to strengthen the sages's didactical aim to ascertain which pupils will remember the list of items. Examples of numerical sayings are found in the Psalter, e.g. in Psalm 62:12-13a.

\section{- Admonitions with and without justifications}

Admonitions imply a warning, command or advice and are not only found in Wisdom literature. Ancient sages ususally introduced an admonition with a justification for the admonition. Sages also applied a more subdued form of admonition with a personal appeal rather than using an admonition imperative in character. The didactical and pedagogical nature of admonitions are key elements and form a central theme in didactic/Wisdom literature as found in Job, Ecclesiastes and Proverbs. In the Psalter admonitions with didactical/pedagogical characteristics are found in Psalms 26:9, 10; $32: 9,19 ; 34: 4,10,14 ; 37: 1,2,3,5,8$ and 49:17, 18.

\section{- Admonitory addresses to "sons"}

The efficient promulgation of Wisdom sayings depended heavily on the attentive presence of willing listeners. It is thus noteworthy that sages addressed their pupils as "sons" (23 times in Proverbs). This form of address is also found in Psalms 34:12; 49:2 and 78:1. 
- 'Ashre formulas

"Ashre-"formulas" introduced by the words blessed/happy express the great concern of Wisdom literature, namely to indicate those who can be regarded as fortunate. This kind of formula is found 45 times in the Old Testament (Job, Ecclesiastes, Proverbs and Psalms) of which 26 are in the Psalter (Ps. 1:1; 2:12; 32:1; 33:12; $34: 9 ; 40: 5 ; 41: 2 ; 65: 5 ; 84: 5,6,13 ; 89: 16 ; 94: 12 ; 106: 3 ; 112: 1 ; 119: 1$, $2 ; 127: 5 ; 128: 1 ; 137: 8,9 ; 144: 15(2 \mathrm{x}) ; 146: 5)$. It is not always clear whether this kind of formula implies a wish or a statement.

\section{- Rhetorical questions}

Rhetorical questions form a key element in Wisdom literature. A question can be regarded as rhetorical if an answer is not expected, but is assumed to be clear from the context of the question. Sages used rhetorical questions as a didactical aid, because it would reinforce the insight of the student. Rhetorical questions are found in Job, Ecclesiastes and Proverbs - in the Psalter present in Psalms $2: 1 ; 6: 6 ; 8: 5 ; 11: 3 ; 18: 32 ; 27: 1 ; 30: 10 ; 34: 13 ; 42: 6 ; 44: 22 ; 49: 6$; $50: 16,17,21 ; 77: 8,9,10,14 ; 94: 9,10$.

\section{- Similes}

Similes are common to Wisdom literature and also served the didactical and pedagogical purposes aimed at by sages. Similes were derived from the surrounding world and were applied as explicit illustrations. Similes were thus easily remembered by pupils, because this kind of similes was well-known to them. Similes are frequently used in Job, Ecclesiastes and Proverbs. Examples of similes can be indicated in Psalms 1:3, 4; 17:12; 21:10; 49:13, 21; $127: 4 ; 128: 3$.

\section{- Words relating to wisdom}

Old Testament books regarded as Wisdom books make use of characteristic vocabulary. The vocabulary, however, does not determine the genre itself. Concomitant with all the other already mentioned features, vocabulary use is, however, helpful in understanding and identifying the concept of wisdom. It can, therefore, be expected that certain sections of Biblical literature containing words and expressions especially identified with Wisdom literature will probably be classified as such. Psalms are for the greater part shorter poems and the fact that a specific psalm does not necessarily contain all the usual words related to the concept of wisdom does not imply that it can not be regarded as a Wisdom psalm. The inclusion of wisdom-related words, however, implies only 
the possibility of a psalm being classified as a Wisdom psalm. Possible words relating to wisdom and most frequently used in the Psalms are inter alia leb (heart, mind - 133 times); yada' (know - 92 times); rasha' (ungodly, wicked - 82 times); derek (way - 66 times and zedek (righteous - 52 times). The frequency of possible wisdom-related words used in the Psalms is the following: Psalm 119 (28 words); Psalm 15 (32 words); Psalm 94 (13 words); Psalms 25 and 55 (12 words); Psalms 19, 37 and 49 (11 words); Psalms 10 and 107 (10 words) and Psalms 1, 5, 73, 92 and 139 (9 words).

\section{- The use of an acrostic structure}

An acrostic structure implies that each strophe commences with the following letter of the Hebrew alphabet and also serves a possible didactic purpose. The alphabet was used by sages to assist pupils in memorising facts. Examples of an acrostic structure is not found in Job and Ecclesiastes but is applied in Proverbs 31:10-31, as well as in Psalms 9/10, 25, 34, 37, 111, 112, 119 and 145.

\subsubsection{Thematic elements}

The second characteristic of Wisdom psalms is the occurrence of thematic elements:

\section{- The fear of the Lord and the veneration of Torah}

The concept of Torah/law (תורה) is discussed below. Within the didactical context this concept can also be translated as an instruction. The wise men of ancient times knew that the fear of the Lord was the origin of knowledge and this fear/knowledge was obtained by intense studying of the Torah. Wisdom literature strongly emphasises the teaching of the fear of $\mathrm{YHWH}$.

\section{- The contrasting life styles of the righteous and the ungodly/wicked}

The term zedek (righteous) appears seven times in Job; 66 times in Proverbs; eight times in Ecclesiastes and 52 times in the Psalter. The term rasha' (ungodly) is used 26 times in Job; 78 times in Proverbs; seven times in Ecclesiastes and 82 times in the Psalter. Contrasting these two groups forms a very important part of Wisdom literature. Righteous people delight in the Torah of $\mathrm{YHWH}$ and are not interested in wealth; they are generous and enjoy prosperity and happiness because $\mathrm{YHWH}$ supports them. The ungodly, on the other hand, do not have compassion, borrow and do not return, are false, cruel, contrive wicked plans against the righteous, but $\mathrm{YHWH}$ damns them and they will perish. These 
contrasting lifestyles are also described in Wisdom literature as the "two ways/roads" of life.

\section{- The reality and inevitability of retribution}

The key problem addressed in Wisdom literature is the injustice of life - the ungodly seem to prosper while the righteous suffer. This great tension of life is treated in Wisdom literature by emphasising the concept of retribution, either in this life or beyond. Psalms 1, 34, 37,49 and 73 highlight this concept.

\section{- Miscellaneous guidelines pertaining to everyday conduct}

Wisdom literature provides guidelines for everyday life, because the wise/righteous must live a life that fits into the order of YHWH's creation. Wisdom literature contains basic advice for everyday life, inter alia instructions to be mindful of the company one is associated with, to live in harmony, be prudent in speech, trust in $\mathrm{YHWH}$, etcetera.

The above characteristics should further be viewed in terms of the three developmental phases of Wisdom literature in Israel's history as identified by Loader (1986:121; 1987:45-46) and Maré (2004:3).

- The first phase was the "unproblematic phase" during which Israel assumed that success is a direct result of a correct lifestyle and failure is the result of an incorrect lifestyle. This phase implied that in a specific situation, YHWH rewarded good deeds and punished bad deeds.

- The second phase was the "dogmatic phase". During this phase, Israel just had to believe that a certain deed would be followed by a specific result. This view implied that prosperity was taken as proof of a man's righteousness, while calamity indicated wrong actions and indicated the suffering person to be ungodly.

- The third phase, the "protest phase", manifested itself especially in the post-exilic period (Friedman, 1981:3). During this phase philosophers realised that misfortune did not necessarily mean wrongdoing or that someone was inherently ungodly. This phase emphasised the boundaries of Wisdom literature and issued a warning that life was much more complex than that which the dogmatic phase allowed for.

In the above discussion the criteria/characteristics used to classify a psalm as a Wisdom psalm were outlined. Burger (1985:152) concludes that both the formal and contextual criteria for Wisdom literature should be met before a psalm fits the Gattung of Wisdom 
psalm. Burger (1985 - see especially the conclusion on p.153-154) indicates that the relationship between the key criteria/ characteristics of a Wisdom psalm forms a triangular relationship between the law (Torah or a synonym for Torah), the fear of YHWH and retribution/vengeance. Using these criteria, the following eight Psalms can be classified as Wisdom psalms: 1, 32, 34, 37, 49, 112, 127 and 128 (see Burger, 1985).

Fig 1 The Wisdom triangle

\section{The fear of YHWH}

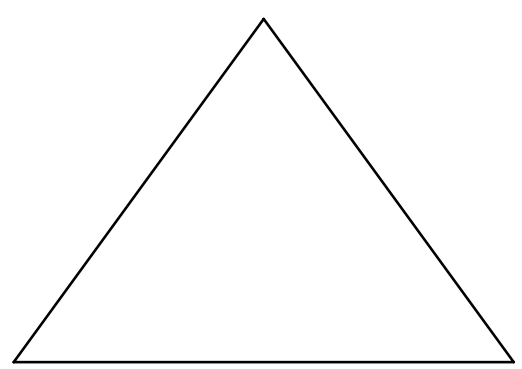

Torah

Retribution/vengeance

As illustrated the above triangle represents the key elements associated with Wisdom psalms and highlights the relationship between the set of key criteria necessary to classify a Wisdom psalm. This triangular relationship between the law (Torah or a synonym for Torah), the fear of $\mathrm{YHWH}$ and retribution/vengeance plays a very important part in the close relationship between Torah and Wisdom psalms that will be discussed in the following section of the article.

\subsection{Torah-related concepts}

Torah-related concepts will be introduced briefly and then expanded upon by investigating Psalm 119 as a Torah psalm. According to Crüsemann $(1996: 1,3)$ a definition of Torah implies the following:

... this Hebrew word is a central concept, and it is an issue Christian theology has only recently begun to address. Christians traditionally discuss Torah under the broader heading of 'law'. Thus, it is often contrasted with 'gospel'. Historically as well as theologically, however, such opposition can only give us a distorted picture of the concept of Torah. 
Torah is concerned with transmitting the one will of the one

God, creator of all humanity, to a single people - His Israel.

The concept of Torah comprises a very wide field of study 5 and contains judgemental/law, moral, cultic, religious, theological and historical statements (Crüsemann, 1996:9). The concept of Torah has many interpretations (see Crüsemann,1996:1, 2):

- Instructions given by a mother (Prov. 1:8; 6:20; 31:26) and a father (Prov. 4:1) to their children to instruct them in matters of living and to warn them against mortally dangerous situations.

- Priestly instruction to the laity (Jer. 18:18; Ezra 7:26).

- Speech of wisdom teachers (Prov. 7:2; 13:14).

- Speech of prophets to pupils (Is. 8:16, 20; 30:9).

- The comprehensive written will of YHWH (Deut. 4:44; 30:10; 31:9).

- Laws (Ps. 78:1, 5, 10; 119).

- The prophetically proclaimed eschatological word of YHWH (Is. $2: 3 ; 42: 4)$.

Thus, in all accompanying interpretations Torah implies the following:

- information

- advice and counselling

- teaching

- the establishment of norms and values

- demands but also support and encouragement

- commands but also benefits

Various authors (inter alia McCann, 1993) see the Psalter in its totality as expressing the inherent qualities of the Torah, because it describes YHWH's will and man's response to it. Whybray (1996:37) is of the opinion that it is not difficult to define Torah psalms and that they should be distinguished from Wisdom psalms. Whybray (1996:37), like Botha (1986:270), also defines Torah psalms as psalms that "concern themselves exclusively with obedience to and meditation of the written Torah". Mays (1987:3) defines a Torah

5 For a detailed discussion, see also Crüsemann (1996); Fitzpatrick-McKinley (1999); Watts (1999); Mann (1988) and Friedman (1981). 
psalm as a psalm in which the instruction of the Lord is the central organising topic and is viewed as the relation between mortal human being and God.

\subsection{Psalm 119 as a Torah psalm}

In this section of the article a short discussion of Psalm 119 will identify specific characteristics/criteria found in a Torah psalm. These criteria will be applied to consider whether Psalm 40 should be considered as a Torah psalm.

A number of authors, including Gunkel (1933:383), Von Rad (1975:200) and Allen (1983:139), consider Psalm 119 to be a Wisdom psalm. Mays (1987:3) states that it is uncertain whether it should be regarded as a Wisdom psalm. Botha (1986:256) concurs with Burger (1985:32) that this psalm is not a Wisdom psalm - the main reason being the strong relationship with individual lament, which distinguishes it from other Wisdom psalms. Botha (1986:175), however, also emphatically explains that Psalm 119's Gattung does not point to individual lament, nor to a hybrid between a Wisdom psalm and individual lament. Although Botha (1986:256) does not use the term Torah psalm, he concludes that Psalm 119 is sui generis and is a declaration of the dedication to $\mathrm{YHWH}$ via the Torah as mutual contact medium.

According to Botha (1986, see e.g 1986:274) the crux of Psalm 119 is the triangular relationship between $\mathrm{YHWH}$, the righteous and the ungodly/enemy. Central to this triangle is the Torah of God. This triangular relationship therefore forms the main element or criterion for a Torah psalm.

Fig 2: The Torah triangle

\section{YHWH}

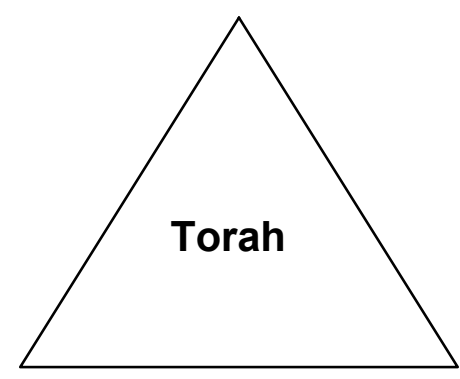

The righteous

The ungodly/enemy 
As indicated by this illustration, the key criterion to classify a Wisdom psalm is to indicate the triangular relationship between the Torah, the fear of $\mathrm{YHWH}$ and retribution/vengeance - this criterion explains the close relationship between Torah and Wisdom psalms.

Anon. (2004b) identifies ten synonyms for Torah in Psalm 119. Botha (1986:271) and Soll (1991:35-37) reduce these synonyms to eight - listed in Table 3.

Table 3: Words relating to the Torah in Psalm 119

\begin{tabular}{|c|c|c|}
\hline $\begin{array}{l}\text { Torah- } \\
\text { word }\end{array}$ & Explanation & $\begin{array}{l}\text { Times } \\
\text { used }\end{array}$ \\
\hline תורה & $\begin{array}{l}\text { Torah - law, instruction, } \\
\text { Mosaic law }\end{array}$ & $25 \mathrm{x}$ sing. \\
\hline עדות & $\begin{array}{l}\text { edut - divine testimony, treaty, } \\
\text { pact }\end{array}$ & $\begin{array}{l}22 \times \text { plural } \\
1 \times \text { sing. }\end{array}$ \\
\hline מצות & $\begin{array}{l}\text { mitswot-commandment, } \\
\text { code of wisdom }\end{array}$ & $\begin{array}{l}20 \times \text { plural } \\
1 \times \text { sing. }\end{array}$ \\
\hline פקדי' & $\begin{array}{l}\text { piqqudim - orders, precept, } \\
\text { statute }\end{array}$ & $22 \times$ plural \\
\hline 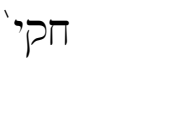 & $\begin{array}{l}\text { chuqqim - statutes, enact- } \\
\text { ments prescribed by God }\end{array}$ & $22 \times$ plural \\
\hline דבר & dabar - word & $\begin{array}{l}19 \times \text { sing. } \\
6 \times \text { plural }\end{array}$ \\
\hline משפט & $\begin{array}{l}\text { mishpat - judgement, } \\
\text { justice, ordinance }\end{array}$ & $\begin{array}{l}18 \times \text { plural } \\
4 \times \text { sing. }\end{array}$ \\
\hline אמרה & $\begin{array}{l}\text { 'imrah - Word of God, } \\
\text { promise, command }\end{array}$ & $22 \mathrm{x}$ sing. \\
\hline
\end{tabular}

Another source (Anon., 2004a) regards derek and zedek (righteous) as two other possible words related to the Torah. Soll (1991:47) does not consider zedek as a Torah-related word, but agrees with the view of commentators like Deissler and Kirkpatrick - like Anon (2004a) - that ten Torah-related words correspond with the Ten Commandments (as proposed by the Massorah) and include derek 
and 'emuna. Soll (1991:47) justifies his decision to use eight words solely on the number of times they are used in Psalm 119. He concludes that derek could not be a word related to the Torah, because it is used only thirteen times. On the basis of an exhaustive grammatical analysis Botha (1986:273) concludes that derek should not be regarded as a word related to the Torah.

\begin{tabular}{|l|l|l|}
\hline $\begin{array}{l}\text { Torah- } \\
\text { related } \\
\text { word }\end{array}$ & Explanation & Times used \\
\hline דר & derek - way, course of life & 13 \\
\hline
\end{tabular}

It is, however, our opinion that, based on the use in other psalms, derek should be included as one of the Torah-related words used in Psalm 119.

Table 4: Torah-related words in Psalm 119 as used in other psalms within the same context

\begin{tabular}{|l|l|}
\hline $\begin{array}{l}\text { Torah- } \\
\text { related word }\end{array}$ & Other Psalms \\
\hline Torah & $\begin{array}{l}1: 2 ; 19: 7 ; 37: 31 ; 40: 8 ; 78: 1,5,10 ; 89: 30 ; 94: 12 ; \\
105: 45\end{array}$ \\
\hline 'edut & $25: 10 ; 78: 5,6 ; 93: 5 ; 99: 7 ; 132: 12$ \\
\hline mitswot & $19: 8 ; 78: 7 ; 89: 31 ; 112: 1$ \\
\hline piqqudim & $19: 8 ; 103: 18 ; 111: 7$ \\
\hline choqqim & $50: 16 ; 81: 4 ; 99: 7 ; 105: 10,45 ; 147: 19$ \\
\hline dabar & $18: 1 ; 33: 4,5 ; 56: 4,10 ; 103: 20 ; 105: 8 ; 147: 19$ \\
\hline misjpat & $\begin{array}{l}1: 5 ; 10: 5 ; 18: 22 ; 19: 9 ; 25: 9 ; 36: 6 ; 37: 6,28 ; 81: 4 ; \\
89: 30 ;(105: 5,7) ; 106: 3 ; 147: 19,20\end{array}$ \\
\hline 'imrah & $18: 30 ; 105: 19 ; 147: 15$ \\
\hline derek & $\begin{array}{l}18: 21,30 ; 25: 4,8,12 ; 27: 11 ; 32: 8 ; 37: 34 ; 51: 13 ; \\
67: 2 ; 86: 11 ; 103: 7 ; 128: 1 ; 138: 5\end{array}$ \\
\hline
\end{tabular}


The previous discussion concluded that the main concern in Torah psalms exclusively deals with obedience to and meditation of the written Torah. Torah psalms also represent psalms in which the instruction of the Lord is the central organising topic. Instruction is viewed as part of the relationship between mortal human beings and God. This relationship resembles a triangle between $\mathrm{YHWH}$, the righteous and the ungodly/enemy. The Torah of God is regarded as the centre of this triangle. This definition will be used for an investigation of psalms that use different Torah-related words in order to identify other possible Torah psalms.

\section{Other possible Torah psalms}

Psalms 1, 19 and 119 have been described as Torah psalms (Mays, 1987:1). The question, however, remains whether there are other psalms that also conform to the criteria for a Torah psalm. It is important to note that the main purpose is not exclusively to find other Torah psalms, but to find psalms which will also comply to the Gattung of Torah psalm in addition to their already recognised list of Gattungen. Not all the selected psalms will be discussed - only those containing Torah-related words and others that clearly conform to the criteria for a Torah psalm. Only the main conclusions from the text analysis will be stated.

Psalm 37 is generally recognised as a Wisdom psalm (see e.g. Burger, 1985:76 and Gillingham, 1994:231). The characteristics of the Wisdom triangle but also that of the Torah triangle can thus be indicated in this psalm The aspects of obedience to and meditation of the Torah are key elements (e.g. verse 31) of this psalm, but do not form the main theme. The law of God is regarded as the guiding principle in the relationship between man and $\mathrm{YHWH}$ (e.g. verse 34). The Gattung of Torah psalm can possibly be added to the Gattungen of Psalm 37, but it is concluded that the concept of wisdom rather than the concept of Torah shaped the Psalm.

As Psalm 78 does not meet enough criteria for a Wisdom psalm (Burger, 1985:101 and Gillingham, 1994:231), it is concluded that although the characteristics of the Torah triangle can possibly be identified, the aspects of meditation of and obedience to the Torah is not the central theme of the Psalm. The impact of the "dogmatic phase" in Wisdom literature on the Psalm is clear. A stronger case can, however, be made to include Psalm 89 in the list of possible Torah psalms. Psalm 89 is described as a Royal psalm (Gillingham, 1994:231), but it can possibly be argued from verses 31-34 and the theme of the Psalm that obedience to the Torah is the central 
element of the Psalm. It is, however, concluded that Psalm 89 is not a Torah psalm. Psalm 94 represents a communal lament (Gillingham, 1994:231) or a combination of a lament and a thanksgiving for deliverance. A direct similarity exists between verses 12 and 13 and Psalm 1:1. The identifying characteristics of the Torah triangle is also present in this psalm. The main theme of the Psalm is, however, not obedience to and meditation of the Torah and it cannot convincingly be argued that this psalm should be regarded as a Torah psalm. Psalm 105 does not meet the stated requirements of a Torah psalm.

Psalm 112 can be considered as the "surprise" of the investigation undertaken. Psalm 112 does not contain the word Torah, but the synonym mitswot. This word choice can possibly be the reason why this psalm has not widely been considered as a Torah psalm. Researchers, including Gunkel and Kraus (see also Botha, 1985:8589 and Gillingham, 1994:231) are unanimous that this psalm meets the criteria for a Wisdom psalm. Even a superficial examination of the Psalm shows that it also meets the previously mentioned criteria for a Torah psalm. The similarity with an established Torah psalm, Psalm 1, is obvious.

If derek is accepted as a Torah-related word, a strong argument can be made that Psalm 25 also meets the requirements of a Torah psalm. As stated in the introduction, the repeated and continued use of the Totius versification of Psalm 25 as a confessional/penitential psalm in the liturgy of the Reformed Churches in South Africa (Gereformeerde Kerke in Suid-Afrika), has contributed to many people's perceptions and experience of this psalm as a Torah psalm - like Psalm 119. In view of the above discussion, it does not appear to be an incorrect view of the Psalm.

In this article specific psalms using Torah-related words were evaluated according to the criteria for Torah psalms. In most cases the conclusion arrived at was that these psalms were shaped by the influence of the perception of the Torah as illustrated in the Wisdom triangle. Psalm 112 clearly stands out as a psalm meeting the requirements of a Torah psalm, although it uses mitswot as a synonym for Torah. In the next section Psalm 40 will be evaluated as a Torah psalm.

\section{Psalm $\mathbf{4 0}$ as a Torah psalm}

Naudé (1999:112-116) indicates that obedience to the Torah is one of the key elements in Psalm 40. Based on this view it can be 
concluded that the criterion is possibly met that Torah psalms are exclusively concerned with obedience to and meditation of the written Torah. The triangular relationship between $\mathrm{YHWH}$, the righteous and the ungodly/enemy in which the Torah forms the centre of the triangle can also specifically be identified in the relationship between verses 5,9 and 15 . The similarity between Psalm 40:5 and Psalm 1:1 and Psalm 119 is clear. In this case it is, however, very difficult to determine whether the Psalm was shaped by the influence of wisdom-related concepts or by Torah-related concepts. It is concluded that both psalms may have been influenced by one of these concepts. It is, however, mainly the characteristics of the Torah triangle rather than that of the Wisdom triangle that are predominantly present. The aspect of fear of the Torah of $\mathrm{YHWH}$, a key element of wisdom-related concepts, does not figure in this psalm. The Totius versification of this psalm therefore does justice to one of the possible Gattungen of Psalm 40.

The connotation with or relationship between the concept of Torah and the concept of wisdom in post-exilic Israel and its role in the final redaction of the Psalter merits further investigation.

\section{Conclusion}

In this article the question was posed whether there are possibly other psalms than Psalm 1, 19 and 119 that can also be considered to fit the Gattung of Torah psalms. In the ensuing discussion Psalm 40 was especially focused on. The close relationship and interaction between the concepts of wisdom and that of Torah were also described. Criteria to identify Wisdom psalms and Torah psalms were deducted. Psalms using different Torah-related words were evaluated and it is thus suggested that other psalms may, apart from their known Gattungen, also be viewed as Torah psalms. A psalm especially meeting these criteria is Psalm 112 and possibly also Psalms 25. It was argued that the Gattung of Torah psalm could possibly be added to the list of Gattungen associated with Psalm 40, but it is not absolutely clear whether the concept of Torah rather than the concept of wisdom mainly shaped Psalm 40. The relation between Torah-related and wisdom-related concepts in post-exilic Israel, as well as the connotations attached to or the relation between these two sets of concepts and their respective roles in the final redaction of the Psalter, definitely offer points of departure for further investigation. 


\section{List of references}

ALLEN, L.C. 1983. Psalms 101-150. Waco: WBC, Word Books.

ANON. 2004(a). General introduction to the Psalter. http://www. christianleadershipcenter.org/504/ppsalmintro.htm [4 August 2005].

ANON. 2004(b). The ten words of Psalm 119. http://www.levendwater.org/ companion/frameset.htm?append73.html\&inhoudsopgave_companion.htm [4 August 2004].

ANON. 2004(c). The Wisdom Psalms. http://www.christianleadershipcenter.org/ 504/wisdom.htm [4 August 2004].

BOTHA, P.J. 1986. Die teologiese funksie van die Torah-woordveld in die driehoeksverhouding Jahwe-vrome-vyand in Psalm 119. Pretoria: Universiteit van Pretoria. (Ph.D.-proefskrif.)

BRATCHER, D. 2002(a). Introducing the Psalms. The Voice. The Christian Resource Institute. http//www.cresourcei.org/psalmsintro.html [23 April 2003].

BRATCHER, D. 2002(b). Patterns for life: Structure, genre, and theology in Psalms. The Voice. The Christian Resource Institute. http//www. cresourcei.org/psalmgenre.html [23 April 2003].

BURGER, J.A. 1985. Die Chokmatiese Psalms. Pretoria: Unisa. (Ph.D.proefskrif.)

BURGER, J.A. 1987. Die Psalms. (In Burden, J.J. \& Prinsloo, W.S., reds. Tweegesprek met God. Die literatuur van die Ou Testament. Deel 3. Kaapstad: Tafelberg. p. 9-40.)

CRENSHAW, J.L. 2000. Wisdom Psalms? Currents in Research, 8:9-17, Oct.

CRENSHAW, J.L. 2001. The Psalms: An introduction. Cambridge: Eerdmans.

CRENSHAW, J.L 2003. Gold dust or nuggets? A brief response to J. Kenneth Kuntz. Currents in Research, 1(2):155-158, April.

CRÜSEMANN, F. 1996. The Torah: Theology and social history of Old Testament Law. Translated by A.W. Mahnke. Edinburgh: Clark.

FITZPATRICK-MCKINLEY, A. 1999. The transformation of Torah from Scribal advice to law. Journal for the Study of the Old Testament. Supplement Series 287. Sheffield: Sheffield Academic Press.

FRIEDMAN, R.L. 1981. The exile and narrative: The formation of the Deuteronomistic and priestly works. Chico: Scholars Press.

GILLINGHAM, S.E. 1994. The poems and Psalms of the Hebrew Psalter. New York: Oxford University Press.

GUNKEL, H. 1933. Einleitung in die Psalmen: Die Gattungen der religiösen Lyrik Israels. (Zu Ende geführt von J. Begrich.) Göttingen: Vandenhoek \& Ruprecht.

JOFFE, L. 2001. The Eloistic Psalter: What, how and why? Scandinavian Journal of the Old Testament, 15(1):142-166.

KUNTZ, J.K. 1974. The canonical Wisdom Psalms of ancient Israel - their rhetorical, thematic, and formal dimensions. (In Jackson, J.J. \& Kessler, M., eds. Rhetorical criticism. Pittsburgh: Pickwick. p. 186-222.)

LOADER, J.A. 1986. Tekste met 'n wysheidsperspektief. (In Deist, F.E. \& Vorster, W.S., reds. Woorde wat ver kom. Deel 1. Kaapstad: Tafelberg. p. 103-122.)

LOADER, J.A. 1987. Spreuke. (In Burden, J.J. \& Prinsloo, W.S., reds. Tweegesprek met God. Die literatuur van die Ou Testament. Deel 3. Kaapstad: Tafelberg. p. 42-48.) 
MANN, T.W. 1988. The book of the Torah: The narrative integrity of the Pentateuch. Atlanta: John Knox.

MARÉ, L. 2004. The Wisdom Psalms as an expression of Israel's worship. Unpublished paper presented at the Pro Psalm Conference. Pretoria: University of Pretoria.

MAYS, J.L. 1987. The place of the Torah psalms in the Psalter. Journal of Literature, 106(1):3-12.

McCANN, J.C. 1993. A theological introduction to the book of Psalms: The Psalms as Torah. Nashville: Abingdon.

McFALL, L. 2002. The evidence for a logical arrangement of the Psalter. Westminster Theological Journal, 62:223-256.

NAUDÉ, E. 1999. Psalm 40: Een of twee psalms. Pretoria: Universiteit van Pretoria. (Ph.D.-proefskrif.)

SMITH, M.S. 1991. The Levitical compilation of the Psalter. Zeitschrift für die Alttestamentliche Wissenschaft, 103:258-263.

SMITH, M.S. 1992. The theology of the redaction of the Psalter: Some observations. Zeitschrift für die Alttestamentliche Wissenschaft, 104:409412.

SMITH, R.L. 1984. The use and influence of the Psalms. Southwestern Journal of Theology, 27(1):5-16.

SOLL, W. 1991. Psalm 119: Matrix, form and setting. Washington: The Catholic Association of America.

VON RAD, G. 1975. Old Testament theology. Vol. 1. Translated from German by D.M.G. Stalker. London: SCM.

WATTS, J.W. 1999. Reading law: The rhetorical shaping of the Pentateuch. Sheffield: Sheffield Academic Press.

WILSON, G.H. 1984. Evidence of editorial divisions in the Hebrew Psalter. Vetus Testamentum, 34(3):337-352.

WILSON, G.H. 1986. The use of the royal Psalms at the "seams" of the Hebrew Psalter. Journal for the Study of the Old Testament, 35:85-94.

WILSON, G.H. 1992. The shape of the book Psalms. Interpretation, 6(2):129142.

WILSON, G.H. 1993. Shaping the Psalter: A consideration of editorial linkage in the book of Psalms. (In McCann, J.C., ed. The shape and shaping of the Psalter. Journal for the Study of the Old Testament. Supplement Series 159. Sheffield: Sheffield Academic Press. p. 72-82.)

WILSON, G.H. 2003. Types of Psalms. http://home.apu.edu/geraldwilson// PsalmTypes.html [23 April 2003].

WHYBRAY, R.N. 1995. The Wisdom Psalms. (In Day, J., ed. Wisdom in ancient Israel. Cambridge: Cambridge University Press. p. 152-160.)

WHYBRAY, R.N. 1996. Reading the Psalms as a book. Journal for the Study of the Old Testament. Supplement Series 222. Sheffield: Sheffield Academic Press.

\section{Key concepts:}

Psalm 40 - different Gattungen

Torah-related concepts

wisdom-related concepts 


\section{Sleutelbegrippe:}

Psalm 40 - verskillendeGattungen

Torah-verwante konsepte wysheidsverwante konsepte 
